\title{
MISCOMMUNICATION IN INTER CULTURE INTERACTION IN SYSTEMIC FUNCTIONAL LINGUISTIC PERSPECTIVE
}

\author{
I Ketut Suardana \\ S3 Linguistik Unud \\ Suardanate920@gmail.com.
}

\begin{abstract}
Bali is one of tourism objects visited by either domestic or international guests because Bali has been trusted to have uniqueness of culture, safety, cleanness and other reasons. Of course, in the process of interaction involving local people and guests (either domestic and international). Miscommunication often occurs in interpreting something during interaction process. One of the reasons is misunderstanding culture owned by the speaker and listener. Doing interaction language is involved in which culture is inside of language. To succeed communication, both speaker and listener must apply the concept of context of situation involving field, tenor and mode purposed by Halliday.

This paper focuses on miscommunication caused by misunderstanding of application of context of situation in community. Halliday stated that whatever we spoke, listen, read and wrote was called text. This paper will analyze miscommunication from Systemic Functional Linguistics (SFL) specially context of situation. Therefore, the title of the paper is "MISCOMMUNICATION IN INTER CULTURE INTERACTION IN SYSTEMIC FUNCTIONAL LINGUISTIC PERSPECTIVE". This paper analyzes some kinds of miscommunication which occurred in community. The result of research is that misinterpretation of text is caused by misunderstanding of culture
\end{abstract}

Keywords: field, tenor, mode, social interaction

\section{BACKGROUND}

Bali is one of tourism objects visited by many guests both domestic and international. They come to Bali because of many reasons such as culture, cleanness, safety and many other reasons. In the process of interaction, the speaker(s) and the listener(s) use(s) language both verbal and nonverbal language, Halliday (1978).

Language itself brings culture of the speakers and listeners since language can not be a part of culture. The more we know about culture the easier to achieve the ideology of the language. If the communication involves participants with the same culture, the participants will not have difficulty in interpreting the message. Conversely, if the communication involves participants with different culture, they will have bigger problem interpreting text than others with similar culture.

What we speak, listen, write and read, is called text, Halliday (1976). Spoken text which can happen in tourism industries (hotel, travel agent, restaurant, airlines) that involves participant with different culture is often found. Miscommunication often comes during the social interaction because of poor cross culture understanding. Even it can lead something bad happen for example discontinuity of relationship, dismissal from company, disappointment or any other bad moods.

To achieve good communication, comprehension of culture especially for target culture is must. The ethic of communication must be applied well. We cannot account that our culture is much more important, valuable, or interesting than other cultures. Respecting other cultures enable social interaction to run well. What we want to achieve is gotten through interaction. If the participants ignore about cross culture understanding, the communication never runs well.

Sometime, the speaker does not know other cultures, he/she speaks to others based on his/her culture, He/she thinks of what is being said will be understood by the 
listener in accordance to what the speaker means. This phenomenon leads to misinterpretation in communication.

There were some guests complaining to what the hotel staff did or behaved to the guests. Even, the case was brought or reported to general manager of hotel or restaurant. In another occasion non-verbal communication can result in misinterpretation of what the doer does or acts, but in other side the doer never thinks of what he did or does can cause inconvenience for others. Another example, guest sometimes didn't understand with language communication when street vendors serving their stuff in tourism object, it was usually miscommunication happen on those situation (Anggayana, Nitiasih, \& Budasi, 2016)

In Bali there was bad viral phenomenon in which there was a tourist from abroad taking a picture, standing on the shrine in one the famous temples. The photo became viral sometime ago, many people living in Bali especially Hindu damped the tourist because of his action. Hinduism felt humbled by the guest, many of them needed the tourist to be reported to the police. But unfortunately, the tourist never felt to make some mistake because of this action. Having being given some explanation about Hindu concept, the tourist apologized for what he had done.

From those cases, this paper discuses miscommunication caused by context of situation related to field, tenor and mode.

\section{THEORETICAL FRAMEWORK}

Living in the world is not as easy as we think because we cannot live alone but we need to live with others. To live socially, we need interaction or communication to exchange information. Without communication we cannot achieve what we want to have.

Agains, Doing interaction involves language, language provides culture inherently, so to speak language, it involves culture, Hall and VVIlliam in Mulyana and Jalaludin (2006) In interaction with community, language must be bound by context of situation. According to Halliday and Hasan (1999), Halliday (2004), Halliday
(2014) and Martin (1992) that context of situation refers to field, tenor and mode. They are integrated or cannot be a part.

Field is related to how the situation works or runs, Field is correlated with what we are doing, what we are thinking, what exists. Those will influence or create situation in which make other persons trigger to give meaning. In addition, field has something to do with how far the relationship the participant of communication and the situation, involving profession whether teacher or doctor or others. Perception is related to thought, it can change situation. Perception is how we change energy of physical environment into our useful experience (Porter and Larry in Mulyana and Jalaludin, 2006)

Tenor refers to participant of interaction. It involves the relationship between or among the participant such as social status in community. The participants can be the writer-reader, speaker-listener, player-audience. The status can permanent or temporary. This term involves negation system such as how the form of clause is used to communicate whether indicative or imperative. From the use of the clause of form, the status of participants can be identified.

Mode refers to controlling field and tenor, it involves the language is used involving register or word choices. The use of register will assist the listener or reader to recognize the field of discussion or how the situation is ongoing. In addition, it involves culture such code, or symbols working in the place where interaction happens, media for interaction belongs to mode. Phonology related to volume, prosody, high or low pitch sound is very significant to create certain meaning.

Doglas (1994) explains the language has very close relationship with situation, they are integrated, cannot be separated one to another. Language can create situation, or situation can trigger the language use.

$$
\text { Language create Situation }
$$

Register is word choices hired based on how the context of situation is going on. In addition, register use represents the topic 
of discussion. According to Douglas (1994) register also involves the language, verb+s/es inherently when the subject is third singular, pronoun based on gender, age and many others.

In English register in verb level can be seen, the verb + s/es is applied if the subject in the clause is third singular such as she, he and it. Pronoun in English such as she, he and it is categorized as register as well.

Back to text, whatever we say, listen, write and read is called as text. Persons do something or activities of course they have reason why the activities are done, called ideology. Ideology is related to idea, opinion of doing something. When ideology is correlated to language, called language ideology. Language ideology refers to why person speak, what make somebody speak, what language is used to encounter the situation context.

\section{METHODOLOGY}

The purpose of this paper is to discuss miscommunication during the interaction between local people and guests. Philosophically, to find the solution of problem, we must identify the Ontology, Epistemology and axiology.

The ontology, some cases were taken in some places for both verbal and nonverbal communication. Each cases was identified based on the context of situation

The epistemology, each miscommunication was analyzed based on context of situation and ideology. Contextual of situation has very close relationship with ideology. Because by understanding ideology, context of situation can be identified. How the field worked, who did something, what symbols was related.

The axiology, how far the finding is useful for community thus other persons comprehend the situation. They do not humble or damp each other. Giving some explanation about culture involving the way to speak, how to behave, how to receive or give something or others is necessity.

\section{DISCUSSION}

Miscommunication often happens in interaction in which involve participants with different culture. Some people do not know that studying a language is studying culture. Studying foreign language means that studying foreign culture. Here are some cases related to problem issued in this paper.

Case I

Sometime ago, there was social interaction in which involved two participants, a guest and a tour driver. The guest was walking in the street, going to beach.

Tour driver: Hi sir, Where are you going? Do you have tour today?

Guest : No. thank you...

Tour driver : I give you cheap price, no one give as cheap as mine.

Guest : No thank you (walk in hurry) From above interaction, miscommunication happened but the driver did not aware that what the tour offered was not needed by the guest, there were some reasons why miscommunication came.

Firstly, the guest did not like to answer the driver's greeting, because the western greeting is related to weather, climate, for example good morning, good afternoon, it is hot or others. However, Indonesian greeting is totally different, in Indonesia Kamu pergi kemana? Apa yang kamu lakukan? are kinds of Indonesian greeting. So the Greeting that can be effective in Indoneia was translated into English, thus the guest felt inconvenient for that greeting.

Secondly, the guest was going to beach, he had fixed plan, no one could interrupt what he had planned before. If the guest makes tour, he will visit a tour counter and he will ask for information instead of being offered in the street.

Thirdly, the word $H i$ is used to greet a person who already recognize each other. In western life if we do not recognize each other, $\mathrm{Hi}$ is not familiar in interaction, but good morning, good day etc is more common.

Such interaction can happen well if the guest has lived in Bali for instance for long time, the guest develops local culture, so the guest knows the way of communication. Miscommunication happened because there was ignorance in context of situation:

1. Tenor, the driver and the guest did not have any relationship in community 
thus the word $\mathrm{Hi}$ was not welcome well.

2. Field, the guest was going to beach, he did not want anyone to interrupt his plan which he had arranged.

3. Mode, It was not appropriate greeting for guest. Where are you going was considered that the driver involve the guest life.

The ideology was to offer tour, actually the driver greeted the guest in order he made tour from the driver but the driver did not comprehend western culture. The driver spoke English from Indonesian translation. Case II

One day ago there was contradicted phenomenon in facebook. There was guest standing on the shrine, taking some photos. This phenomenon became viral, most Hinduism damped him even some of them reported the man to the police,

From this phenomenon, we can see why a such event happened, we can analyze a such phenomenon based on context of situation.

1. Tenor, the actor was the guest,

2. Field, the actor did not know what could happen when he did a such action.

3. Mode, the guest did not comprehend about the value of shrine because it was the first time he knew shrine which Hinduism hold tightly.

It deserved that Hinduism damped because they think that the place is very holy, the place where they can connect themselves to the God. That place must be sterilized from unholy action which can break Hinduism belief.

The purpose why he did a such event because he knew that the place was very interesting that he had never seen before. He wanted to take photo in the place. In addition, the place where he took a photo is very high, he could see more view.

Finally the guest apologized of what he had done and Hinduism accepted because they understood what he did but did not know the effect. The guide who escorted him should have given some explanation regarding to role and regulation before visiting holy place, temple alike.

We must not aggravate situation because we must know the ideology why the guest did a such event and how the context of situation worked in that time. It is not good to punish someone without understanding the ongoing context of situation.

\section{Case III}

In a famous restaurant, there was a guest going to restaurant, in the front of restaurant there was a hotel employee walking and saying "do you want to eat". This utterance was used as greeting as Balinese people do.

Employee : Good morning sir, do you want to have lunch. Our restaurant provides some kinds of menu you like.

Guest : What.............. You must not involve my business. That is not yours.

Employe : Are you insulted of what I said? If so, I am so sorry. I apologize for being inconvenient.

Guest : : Go away. I do not like to hear a such word. (the guest was very disappointed with the employee).

Employee : I am so sorry ( leave the guest, felling something worried, even $\mathrm{He}$ was worried whether this problem will be reported to the manager)

When we look at the social interaction above, misinterpretation of the greeting caused the situation to get changed. We can analyze this miscommunication based on:

1. Tenor, the interaction involved two participants. The first participant was the guest living in a hotel, the second participant was the employee of the hotel. The employee did not work in the restaurant, he just greeted the guest. The guest did not have plan to have lunch but the guest only passed the restaurant where the others were eating some meal.

2. Field, the guest wanted to go somewhere and passed the restaurant while the guest was thought to have lunch hence he was suggested making order in the restaurant. The situation became inconvenient for both participants. 
3. Mode, the employee did not know what western culture was like. The employee wanted to treat all guests living in the hotel by applying greeting based on his own way. In another side, the guest holds his own culture mind tightly that every person who enters to the restaurant is not sure to have some meal, but there are some other purposes why a person come to a restaurant. According to the guest, a person who came to the restaurant did not have to be greeted in that way. But just enough say good morning, good afternoon.

The ideology why the employee did a such way because the employee wanted to appreciate everybody or guest staying in the hotel. Because being staff of the hotel, respecting other is must. In tourism industry, giving the best service becomes the first priority because when the guest feels satisfied they will tell to others about what they experienced.

\section{Case IV}

In one "Rumah Makan" located in Bukit Jimbaran, one of the restaurant assistant welcomed a guest driving a bike. He ordered noodle in the restaurant.

The restaurant used to serve local people for some food, the servants never handled western food

Guest : Can I have some tea and some noodle please!

Servant : Yes sir.... please (prepare everything for what he ordered)

Guest : Stupid.....stupid........how stupid you are. You do not understand what I mean. Haaa.........haaaa (the guest left "Rumah Makan")

When the servant came to bring what the guest had ordered, the servant smiled and prepared on the table. But unfortunately what the guest ordered was not like what he needed.

1. Mode, noodle conceived by the servant and the guest was totally different. The concept about noodle from the servant was "Sarimi, Indomie, Mie sukses" But it was totally different from the guest, noodle cooked from restaurant or hotel. The guest laughed too loudly to see what the servant was preparing.. The guest say "stupid.......stupid...how stupid you are"

2. Tenor, the participants involved in social interaction were the servant and the guest.

3. Field, firstly, the guest came to "rumah Makan", the guest wanted to have some meal, he ordered a glass of tea and noodle. He was very tired and exhausted. The guest laughed too loudly and made the servant felt ashamed because they have different concept of noodle.

\section{CONCLUSION}

When we look at back why miscommunication occurred either verbal or nonverbal communication were caused by misinterpretation. Misinterpretation may become more inconvenience even the participant damped each other. They claimed that they do not do any mistake but they do something right. On the other side,, there were some persons accuse others do something wrong. This is because they bring their own concept and they hold tightly.

When this principle is done without comprehending other culture, communication does work well. In fact we need social interaction with others either from home country or foreign countries. To make communication well we must tolerate based on contextual involving filed, tenor and mode.

To accelerate tolerance for good communication, we must know ideology why someone does something. Because ideology will help us to identify how the context of situation works.

\section{REFFERENCES}

Anggayana, I. W., Nitiasih, P. K., \& Budasi, I. G. (2016). Developing English For Specific Purposes Course Materials For Art Shop Attendants and Street Vendors. Jurnal Pendidikan Bahasa Inggris Indonesia. accessed in http://119.252.161.254/ejournal/index.php/jpbi/article/view/20 42 
Biber, Douglas and Edward Finegan.1994.

Socilinguistic Perspectives on

Register. New York: Oxford University

Press.

Mulyana, D and Rahmat, J (Editor) . Komunikasi Antarbudaya Panduan Berkomunikasi dengan Orang-Orang Berbeda Budaya. Bandung: PT Remaja Rosdakarya.Halliiday and Hasan. 1976. Cohesion In English. London: Longman.

Halliday and Hasan 1999. Language, Context, and Text: Aspect of Language in Social-Semiotic Perspective. London: Deakin University.

Halliday. 1978. Language as Social Semiotic. London: Edward Arnold.

Halliday 2014. Halliday's Introduction To functional Grammar 4th Edition. In Matthiessen(revise). London and New York: Routhledge.

-2004. An Introduction To Functional Grammar 3rd Edition. London: Arnold.

Martin, J.R. 1992. English Text System and Structure. Amsterdam: Johnbenjamin Publishing Company.

Porter, E. Richard and Larry A. Samovar. 2006 "Suatu Pendekatan Terhadap Komunikasi Antarbudaya" in Deddy Mulyana and Jalaluludin Rahmat (Editor) Komunikasi Antarbudaya Panduan Berkomunikasi dengan Orang-Orang Berbeda Budaya. Bandung: PT Remaja Rosdakarya. 